\title{
The Coyote Came Back The Return of an Ancient Song Dog in the Post-Colonial Literature and Landscape of North America
}

The Buffalo herds have gone; they have succumbed to the rifles of the hunters. The antelope droves are nearly gone; hound and lead were too much for them. The blacktail bands have dwindled before axe and fence. The ancient dwellers of the Badlands have faded like snow under the new conditions, but the Coyotes are no more in fear of extinction. Their morning and evening song still surrounds from the level buttes, as it did long years ago when every plain was a teeming land of game. They have learned the deadly secrets of traps and poisons, they know how to baffle the gunner and the Hound, they have matched their wits with the hunter's wits. They have learned how to prosper in a land of man-made plenty, in spite of the worst that man can do.

-Ernest Thompson Seton, Lives of the Hunted

Ho, ho, ho! You can never kill us Coyotes! We live forever.

-Jaime De Angulo, Indian Tales

I used to debate the ethics of hunting with a colleague when I lived in the near-north of Ontario. He has told me many times that hunters never kill just for fun, but engage in an almost spiritual rite of survival and sacrament while they pursue their quarry. More importantly, he says, the ethical hunter abhors waste and eats everything that he/she kills regardless of the "sporting" nature of the event. I had accepted many of these arguments, but once overheard my friend talking to a 
group of hunters about how many coyotes they had killed. I asked him if he enjoyed eating coyotes. He replied sheepishly that no, coyotes did not make for good eating, but they killed a lot of rabbits. I asked him if he felt at all nervous killing an animal who possessed the mythic god-powers of a Trickster. No, he told me, coyotes were nothing but a garbage animal.

God or garbage; bane or blessed-on these axes revolve the multifaceted relationship of human beings to the coyote. The animal is a sacred Trickster and godlike being to various Native nations in the western parts of North America, but is also a persistent "pest" for the livestock raisers who now live in the same area. Livestock owners, hunters, and control agents across North America relentlessly pursue the animal as if the survival of human civilization were hanging in the balance. Today it is sheep, some stock raisers and hunters have told me; tomorrow it will be somebody's children. The only possible response to such a "threat" is yet another campaign of extermination, and in many agricultural areas the rustic beauty and harmonized simplicity of the rural landscape hides a savage field that is soaked in blood and poison.

However, the coyote is not always understood as "garbage" in the contemporary human experience. A Canadian Wildlife Service document from two decades ago describes the coyote as "a challenge to American man" because "it is both likable and detestable in character," a creature who "seeks man out while it flees from him, mocking his attempts to exterminate it." The coyote should be admired, the document explains, as a remarkable survivor, the only large carnivore who has managed to extend his range throughout the rural, urban, suburban, and far wilderness landscapes of North America despite the widespread persecution of human beings (1). As an ecological and ontological margin-dweller (between different ecotypes and between the worlds of civilization and wilderness), the coyote continues to generate interest among humans in the classic myth-Trickster mode. He appears to many of us at the edges of fields and forests, and his sharp, staccato laughter reverberates through the forest to bring us news from the alien world of the "Others." 1 As an animal who now appears to us in cities as well as in rural areas and the raw wilderness, Coyote's biological and metaphorical versatility continue to be, as Paul Shepard suggests in The Others (1996), "a gift to human thought" (23).

Accordingly, the coyote has withstood the assault of the "cultivated" Western mind in an almost eerie parallel with his resistance to the cultivated landscape. Coyote stories of the Native West have survived in both oral and written forms, and the character has more recently expanded his range into the imaginative realm of contemporary po- 
etry and fiction, forming a very specific and marginal sub-genre within the larger body of North American literature (even providing the inspiration for an influential experimental literary journal begun by James Koller in the early 1970s-Coyote's Journal). Coyote has also been adopted as a potent meta-textual symbol for the narrative and poetic experimentalism that has characterized much of North American literature in the last forty years and, as a continued physical and metaphysical "presence" in the landscape, he has begun to figure into the philosophical debate surrounding the relationship between humans and the natural world.

We have spurned the coyote and he has come back to us. He may be an elusive spirit who is, in the words of Simon Ortiz, "just trucking along," or "heading to Tulsy Town I guess," but, in the end, "He'll be back. Don't worry. / He'll be back" (160). What follows is largely a celebration of his return, an attempt to uncover the some of the larger literary and philosophical issues surrounding the recent subversive re-sanctification of the relationship between human beings and the coyote. Along the way, we will meet many of the symbolic and physical manifestations of the coyote: the urban coyote, the mythic "liminal" animal of pre-modern Native North America, and the resurrected "postmodern" Coyote of recent times.

\section{The Ancient Roots}

The ancient myth-character of Coyote is an enigmatic paradox whose "nature" is both multi-faceted and constantly shifting. He appears variously as a wanderer, a glutton, a lecher, a thief, a spoiler, an outlaw, and a horny old man; but also as a loser, a builder, a pragmatist, and a survivor. His contradictory nature and locally-colored personality resists universalizing academic interpretation, but is, in each of his manifestations, merely one aspect of an elusive protagonist, a source of the "Dadaistic energy" that Gary Snyder has found so compelling in the Coyote myths (The Old Ways 81).

Such a localized and varied "nature" for the coyote suggests that the mythical character was at least partly a response to the outward manifestations of the biological animal. Although little is known about the material relationship between pre-contact peoples and the biological coyote other than the probability that many village groupings kept semidomesticated coyotes in their midst, ${ }^{2}$ Paul Shepard suggests that "the animals of myth are like the composite soul of species," and "the Navajos, for example, never overlooked a larger context for their Coyote stories, a world in which people are surrounded by real coyotes that catch mice, scratch fleas, and defecate" (93). Thus, on a very basic level, 
stories about the coyote-as-scavenger/thief, or those concerning the problematic hunting partnerships between the badger and coyote reflect basic social and ecological relationships, rather than a myth-world that is transcendent in the human soul. ${ }^{3}$ For example, the story "Coyote Establishes the Fishing Taboos" confirms the central tenets governing a particular human/fish relationship, an ecology that is learned from the "trial and error" mis-adventures of Coyote:

He took a shit, he said to his shit, "Tell me,

Why have those silversides disappeared?"

"Oh, you have no sense, you bandylegs!

"When silversides are caught, when they are first caught, they must not be cut up.

"They must be split along the back, then they are roasted, they are not steamed.

"When they go upriver to the creeks, Then they are steamed." (Ramsey 40)

Clearly, if traditional Coyote tales are not necessarily archetypal myth statements of the Jungian sort, then they are also not simply mere entertainment. The stories are often funny, bawdy, and outrageous, but they are also teaching stories that may, as in the example above, reinforce the ethical principles and ecological practices of a particular locality. The Navajo storyteller Yellowman has said that "if my children hear the stories, they will grow up to be good people; if they don't hear them they will turn out to be bad" (quoted in Scott and Toelken 80). Even in the stories where Coyote exhibits morally reprehensible behavior, as in the widespread tales of his acts of incest and rape, there is a paradoxical affirmation of societal restrictions on this type of behavior because Coyote can be laughed at as one who should know better. Through Coyote's ridiculous behavior, the stories become expressions of what not to do, in Scott and Toelken's words, "cultural references against which the morality of Coyote's actions may be judged" (87).

Conversely, Coyote is not only a spirit of moral negation, but also a "fixer" who places things in the world as they should be, creating order and form out the disordered natural world. A Maidu story, for example, depicts Coyote creating the world hand in hand with the Earthmaker. He also kills monsters and giants in the classic European 
heroic mode, herds fish into the appropriate rivers, steals fire for the people, and removes teeth from women's vaginas. ${ }^{4}$ An Okanagan story collector by the name of Mourning Dove remarks in Coyote Tales (1933) that "Coyote did more than any of the others [i.e. the animal people] to make the world a good place in which to live" (7). Thus, for many precontact cultures, Coyote was (and remains) a high-ranking clan deity, the provider of procedures, prayers, songs, medicines and paraphernalia for intense rituals such as the nine-night Navajo Coyoteway healing ceremony. These rituals, according to Scott and Toelken, help human societies "conceive of order" within a chaotic universe, and "the Coyote materials, then, may be seen as ways of conceptualizing, of forming models of those abstractions which are at the heart of Navajo religion" (90).

Despite the obvious manifestation of Coyote as a sacred teacher, anthropologists such as Toelken have quite likely overstated the role of Coyote as an ordering principle, partly as a response to critics who have dismissed the material, but also in reaction to those such as Jung who saw in the Trickster-Coyote an absolute expression of archetypal demonic inner chaos (205). Whether by affirmation or negation, Coyote does act as an agent of order within a large number of stories. However, chaos is never fully rejected by the Coyote-protagonist either, and much of his constant trickery never lands clearly on one side of any social or moral equation. Many of Coyote's exploits are not resolute actions, but begin and sometimes end in media res, ${ }^{5}$ often with words that are a variant on the title of Jarold Ramsey's collection Coyote Was Going There (1977). Thus, like his biological cousin, the mythological Coyote is an incessant wanderer, a "flux-being" whose exploits often take place outside the social order of the local community. He is often seen floating on rivers where, like Huckleberry Finn, he plays random tricks on, or gets tricked by, the shoreline inhabitants and then moves back to the middle ground of the flowing water. One story, called either "The News About Coyote" or "Coyote Sucks Himself," contains many of these elements and is worth quoting at length:

He went, he was going along,

now he thought:

"I shall suck myself."

He went on,

off the trail, he covered himself with five rocks, now there he stayed.

He sucked himself, he finished, he came out. 
He was going along,

he saw a canoe going downriver,

he thought,

"Let me inquire of them.

"Perhaps something is news."

He hallooed to them;

they heard him,

they told him,

"Ehhh what?"

He told them,

"Isn't something news?"

"Indeed. Come a little this way."

He went close to the river.

"Yesss,"

they told him;

"Coyote was coming along,

"now he covered himself with rocks.

"He sucked himself,

"Such is the news that is traveling along."

He thought,

"Hmmmm! Wonder who saw me?"

He went back,

where he sucked himself at;

he saw,

the rocks are split,

where the news had rushed out.

He thought:

now he said:

"Indeed,

"even though it was I myself,

"the news rushed out."

"Now the people are near.

"Whatever they may do,

"should they suppose,

"No one will ever make me their news,

"out it will come." (Howard and Jacobs 70-72)

Throughout the story, Coyote's indulgent, masturbatory, and solitary behavior places him at odds with the social demands of the encroaching human community. His self-burial and pointless sexual activity suggest an isolated, death-like status for the participants in such anti-social behavior. As a self-indulgent wanderer, Coyote displays what Jarold Ramsey has described as "the intolerance of domesticity in any form: he is, like one of his sly animal totems, essentially a self- reliant loner, a potentially disruptive outsider in his appetites and capacities 
even when he is temporarily domiciled" (Reading the Fire 30). In contemporary terms, Coyote is a self-willed force of nature acting against a self-imposing human culture. His retreat across the river and away from human social structures renders him a hermit-like deviant who must, to fulfill his most basic impulses, hide from the oppressive domestic morality of human society. Yet, his scheme to completely immerse himself and disappear into the inanimate and nonhuman word of rocks ensures that he will become an object of ridicule as the "news" floats down the river. Coyote learns that so long as humans define themselves as a distinct cultural entity, the news about all "others" will be understood purely in their terms. There is no ontological space for the autonomous (i.e., masturbatory) behavior of nonhuman beings who now exist merely as an oppositional and categorical reference point of judgment and ridicule against which humans may interpret the world.

However, in the myth-world of Coyote, the boundaries between human and nonhuman categories are not as rigid as they first seem. Indeed, much of "The News About Coyote" takes place not in the oppositional world of the village vs. Coyote, but in the liminal space of the unnamed river. The human "eavesdroppers" make no attempt to banish Coyote from human society to his rocky masturbatory underworld, nor does the ridicule he endures cause a retreat from the dialectical world of the river. Indeed, the story resolves itself not only with the denigration of, but also with an ironic sympathy for, Coyote's forced interaction with the world of human cultural norms. Humans are, after all, the ones who are telling the story, and there is an empathetic respect for Coyote, not only as a figure of humorous delight for the residents of the human social world, but also as a bearer of "news" from the nonhuman world which is "passed on" in the inbetween space of the river. Lévi-Strauss suggests in Myth and Meaning (1978) that this mediative role is derived from the coyote's status as an omnivore that is "in-between" carnivores and herbivores (22). Certainly, his status as an ecological margin-dweller has further contributed to the human perception of Coyote as a liminal figure who carries over symbolic patterns to and from the world of wild nature. Throughout the Coyote myths, the space between nature and culture is, like Coyote's rock house, more a permeable membrane than a permanent boundary, and so the Coyote myths, to large extent, have never been domesticated. Unlike the more "cultivated" agricultural myths in which, as Sean Kane describes it, "the world of human effort is imagined to be pitted against a world of shadowy forces 'out there"' (239), the Coyote myths admit the possibility and inevitability of wild and unpredictable behavior. There are no attempts in the stories to control Coyote or make him predictable, an implicit recognition of 
flux and ambiguity as philosophical ordering principles. As Jarold Ramsey explains,

To believe that the world as we have it is largely the work of a trickster is, in a mode of thought unfamiliar to our culture, to know and accept it on its own terms, neither postlapsarian nor millennial: as if to say, "Well, now, the world is not perfect; how could it be, given its original artisan, our trickster ancestor-but it's pretty good, considering; good enough, anyway." (Reading the Fire 41)

The Coyote, at least in the traditional cultures of western North America, is connected to this near collapse of structure and anti-structure; creativity and destruction; domesticity and wildness. He brings both the first birth and first death to the world. He is both a lawmaker and a transgressive figure; a giver of gifts and a thief; a gluttonous hunter and a creator of fishing taboos. In other words, myth-consciousness is Trickster-like because it is both a pattern and an anti-pattern; a rigid code and an expression of imaginative possibility. Of course, mythical thought is more properly understood as the byproduct of a storytelling culture, and the Trickster-paradox of disharmonized harmony can therefore be understood as a meta-text for oral expression. Stories told again and again within a particular community contain both an elusive locus of possibility and also the constraining boundary of traditional narrative's collective remembrance. Incongruity becomes the lifeblood of the story, maintaining the audience interest, but also allowing for the passage of particulars from one contextual frame to the next.

What emerges from this process is metaphorical thought, which in the Greek literally means "carrying from one place to another," a function that, as we have seen, Coyote performs with admirable dedication. Coyote is a constant thief; a continual visitor to the land of the dead; and, as we have discussed, a bumbling introducer of new laws and natural phenomena such as one-way rivers and death. In the Okanagan language he is Sin-ka-lip', the Imitator (Mourning Dove 7), an entity that juxtaposes one identity-pattern with another to, in LéviStrauss's terms, move toward a resolution of discontinuities. Metaphorical knowledge-as-Coyote is therefore a constantly shifting, elusive entity, both one thing and another at the same time, a fluid reality where one thing can be whole only when it is understood as part of a different context. This was the lesson of Marcel Duschamp when he put a toilet in an art gallery and called it a fountain; it is the lesson of the Coyote-Trickster when, in one common story, he puts pitch balls in his skull and calls them eyes.

Of course, the metaphorical structures of traditional Coyote tales are not simply the pure disembodied fabulations common to the Dadaist 
school. The meta-exploits of Coyote are, as we have seen, firmly grounded in the physical world, and myth creation is, according to Lévi-Strauss, a process whereby "images borrowed from experience can be put to use." Herein lies the key to "the originality of mythical thinking," which is "to play the part of conceptual thinking." Thus, as with the example of Coyote, "an animal which can be used to what I would call a binary operator can have, from a logical point of view, a relationship with a problem that is also a binary problem" (Lévi-Strauss 22-23). There is, then, a continuum between physical and meta-textual boundaries in the mythic expression pre-modern thought patterns. It is here, in the liminal space between conceptual and physical boundaries, that an undifferentiated experience of the natural world may proceed. As Sean Kane explains, "the forest-edge, the sea-surface, the sky, the holes and caves in the earth, the transformation rituals, the boundary goddesses-these are all epistemological frames, markers of categories of knowledge, saying in effect: 'Beyond this point is a zone where ordinary thinking cannot go. You must make the shift to another kind of thinking. You must think like an animal now. Enter at your peril'" (113). At the precipice of these edge-boundaries stands both the mythic and the biological Coyote, ready to confer knowledge to humans on the other side of the ontological divide-ready, in the end, to teach us how to think like a coyote.

Of course, by suggesting a framework of shared continuity for coyote/human relations in pre-contact North America, I do not mean that there that there was an absolute, noble savage-like harmony between the two species. Coyote is, after all, a harbinger of both order and chaos. His mythic character is complex and contradictory. Gary Snyder warns that "the Trickster is a delightful literary conceit, but an unpredictable Ally-dangerous and very potent," who could "destroy any poet who got locked into it" (The Old Ways 88). Indeed, to regard the world as a Trickster-phenomenon is to reject notions of harmony which are, if truth be told, the invention of pastoral/agricultural societies intent on homogenizing and controlling "their" immediate environment. The sterility of such harmonious landscapes spills over into the resulting literary productions, as any honest person who has been tortured by the various European pastoral poems and eclogues will surely tell you.

The "trickster-nature" of the Coyote myths is, by contrast, full of vitality, and little that is "vulgar" is hidden within the events of the stories. Such seeming frivolities such as huge erections, farting, constant sex, and conversations with shit are all present alongside the more cosmological events: the creation of the universe, the first birth, and the introduction of death. The stories are, by our own Puritan standards, a vulgar teleology that is best summed up by the chaos-accepting street wisdom of the phrase "shit happens." And happen it does, 
through story after story of outrageous imaginings, a mythic acceptance of flux, change, and randomness that can only be matched in the ancient Western world by the subversive outpouring of Ovid's Metamorphoses. But unlike Ovid's work, the Coyote myths were never banished by their originators. They remain central to a view of the world as an elusive, uncontrollable Trickster-entity that will not respond to strict human boundary-making exercises. Most significantly, the Coyote myths contain an abundant and irrepressible sense of humor about this situation, the feeling that a world of flux that is at least partly beyond human control may actually be more interesting and, indeed, more fun than a predictable, monocultural planet. This sense of humor has largely been lost on modern humans and their obsession with imperial control over the natural world, a lack of "other" indulgence that has had dire consequences for the North American coyote and the rest of wild nature. Nonetheless, Coyote remains in the landscape, a source of merriment and buffoonery that has survived the radical incursions of European colonialism, a wellspring of vital energy that has recently been rediscovered by the pioneering progenitors of a postimperial, postmodern conception of the natural world.

\section{Coyote Sings a New Tune}

It is a mistake to think that the contemporary literary Coyote is simply a clever metaphor that has been resurrected by alienated and uprooted Anglo-American writers who lack a set of cultural symbols to call their own. Indeed, the return of Coyote is not a new phenomenon, but a testament to survival of Native North American cultures in the face of the Neo-European empires in America. An early example of this tendency can be found in a Diegueño story from Mexico, which exploits the "thief" aspect of Coyote's personality to create a composite portrait of the religious authorities of the Spanish Colonial regime. The action of the story simply involves a Coyote/missionary coming to a farmer's wife each day and asking to baptize a chicken. Of course, Coyote eats all the chickens, and the woman is left without a livelihood or a means to seek restitution. Coyote's "predatory" behavior therefore offers a powerful allegorical warning to resist the seductive tactics of the Spanish missionaries, and also a familiar cultural reference point from which to judge the missionary behavior in the classic Trickster-negation mode. As a representation of "what not to do," the Trickster-Coyote provides not only an internal confirmation of core cultural values, but also a means to identify and resist an external threat to the community's basis for cultural survival (Murillo 89-91).

Contemporary Native writers continue to explore Coyote's poten- 
tial as a subversive counterforce to Western colonialism. In One Good Story, That One (1993) Thomas King, for example, depicts Christopher Columbus meeting Coyote at the explorer's arrival point in the Americas; his story "A Coyote Columbus Story" is part of a larger effort to poke fun at the European claim to have discovered the "emptiness" of a New World (119-127). King further exploits these anti-colonial possibilities in his novel Green Grass, Running Water (1993), casting the Coyote as an anti-fixer who makes the world right by unleashing his destructive energy on a huge and exploitative dam project in a Blackfoot reserve in Southern Alberta. The Acoma Pueblo poet Simon Ortiz similarly invokes Coyote as a symbol of resistance to the developmental tendencies of the colonial mindset. In this case, Coyote is not so much a spirit of disorder as he is a highly transcendent and redemptive spiritual entity. In his poem "Grand Canyon Christmas Eve 1969," Ortiz expresses dismay at the tourist developments, the fees, and the regulations he must face when he returns "home" to the ancestral lands that now make up Grand Canyon National Park and the Kaibab National Forest. However, he believes that salvation is possible for the postcolonial world through the return of the Savior-fixer figure of Coyote:

Here it is possible
to believe legend,
heros praying on mountains,
making winter chants,
the child being born Coyote,
his name to be the Christ.
Here it is possible
To believe eternity. (188)

All of the above works affirm that the Coyote of Native myth has never died. Indeed, his relatively recent (post-war) appearance in nonNative works of fiction, poetry, and drama represents a significant crosscultural expansion for the song dog of the mid-west. Gary Snyder attributes this "transmission" of Coyote material to the proliferation of relevant anthropological texts, to the appearance the "bohemian hero" (see Jaime De Angulo's 1953 book Indian Tales), and to the direct oral experience of the stories on hitchhiking forays throughout the Western part of the continent. By the 1950s, the West Coast writers associated with the burgeoning beat movement began to identify with the "outsider" image associated with Coyote, just as they had aligned themselves with the underground marginality of African-American be-bop culture. As Snyder explains in The Old Ways (1977),

The Trickster presents himself to us as an anti-hero. The West was heroics, but as you know, in the fifties and sixties we didn't feel 
like heroics, we felt more like anti-heroics, and the Trickster is immediately an attractive figure for the same reasons that you find anti-heroics in the writings of post World War II French and Italian or English writers. Artaud is a Trickster, William Burroughs in his novels talks out of the side of his mouth with a kind of half Coyote, half Dashiell Hammond dry style. So the Trickster image is basic. (84-85)

Suddenly, the polyphonic and electric spirit of Coyote began to appear everywhere in literature as a figure that was both dangerous and lifegiving at the same time. Snyder's poem, "The Berry Feast," from The Back Country (1957), was one of the first to use Coyote as an image, and it celebrates the Trickster's vital "bohemian" powers of negative enchantment:

Fur the color of mud, the smooth loper

Crapulous old man, a drifter,

Praises! Of Coyote the Nasty, the fat

Puppy that abused himself, the ugly gambler. (1-4)

Subsequent poets such as Barry Gifford, Lewis MacAdams, Will Staple, and Bruce Bennett have picked up on this theme and expanded its range of possibilities. In true Trickster fashion, Barry Gifford's book Coyote Tantras (1978) cries out in tantra XXX for "no more laws" because "chaos is a myth created by men." In tantra XXXVII, the poet invokes Coyote as the "noblest / of all medicine men, witch doctors and shamans, / priests and hobos," encouraging him to "trample the hatred and lies of this life / \& MAKE MEN FREE."

By contrast, Bruce Bennett's "Coyote in Love," included in William Bright's A Coyote Reader (1993), casts the song dog as more of a lecher and liar, a source of prodigious fertile sexual energy that feeds the "outsider" poet's creative faculties:

Sure I've done it with other women

but you're the one I'm always touching

So Coyote

tells his women

who always believe him.

Or so he tells me. (72)

Although he is not primarily a poet, the anthropologist Dell Hymes's "Fivefold Fanfare for Coyote" (Bright 50-54) expounds on all of these possibilities, and perhaps best articulates the multifarious "nature" that has been ascribed to the modern myth-animal:

mousing, mating, mischieving, metamorphosing!

malingering, mimicking, miscible mirror! 


\section{Misogynist-Mongrel-Munchausen-Minster-Muse!}

fooling friends, foiling foes, featly transforming friends \& finagling, fingering, fucking, forsaking females \& fixing flora \& fauna in future functions \& fabricating facilely, foraging fortunately, famously Fecund Factotum

$$
\text { Fornicating Physician }
$$

FOUNDER!

befuddled, besmirched, beleaguered, belittled begetterprofane, prophylactic, prolix, procrustean precursor-

$$
\begin{aligned}
& \text { WANDERER } \\
& \text { MISCREANT } \\
& \text { FORNICATOR } \\
& \text { BUNGLER } \\
& \text { PRONOUNCER. (52) }
\end{aligned}
$$

Among fiction writers, Canada's Sheila Watson was one of the first to fully articulate the mythic reality enhancing powers of Coyote. Her groundbreaking 1959 novel, The Double Hook, is a spare, allusive, and fragmentary narrative account of a group of characters living in the Cariboo country of British Columbia. The substance and circumstances of their lives are conflictual and contradictory, and the novel is constructed within a landscape of paradox and uncertainty. As one character (Greta) remarks, "there's something fixed about a pump, fixed and uncertain" (14). For another character (James), "the land below seemed ordered and regular, but as his horse slipped down over the shale into a clump of pines he wondered where in all the folds and creases he would find the girl" (111).

The mythic Coyote permeates every aspect of these elusive relationships: singing to the characters, calling them to death, and carrying cryptic messages across the hills that surround the settlement. The action of the novel takes place "under Coyote's eye," and the efforts of one character (James) to escape the community reflect an inability to live within the myth-structured constraints of a Trickster landscape:

He [James] is like his old lady, Kip thought. There is a thing he doesn't know. He doesn't know that you can't catch the glory on a hook and hold on to it. That when you fish for the glory you catch the darkness too. That if you hook twice the glory you hook twice the fear. That Coyote plotting to catch the glory for himself is fooled and every day fools others. He doesn't know, Kip thought, how much mischief Coyote can make. (51)

However, in accordance with the mythic tradition, Coyote is not merely a destructive personality within the novel. He is also the physi- 
cal and conceptual conduit through which many of the characters become connected to their "place" in the larger scheme of the world. When a child is born at the close of the book, we hear

Coyote crying down through the boulders:

I have set his feet on soft ground;

I have set his feet on the sloping shoulders of the world. (118)

Coyote therefore creates the conditions for "being" within this particular location, and makes existence itself possible through the application of his creative capacities. He is not merely an aspect of reality; reality is instead an aspect of Coyote, and indeed, Watson's experience of the Cariboo country as a teacher in the 1930s was that of a country of opposites, a landscape of paradox that was perfectly reflected in the Coyote stories of the local Shuswap people. Her creative dialogue with the Cariboo country is therefore, like the one experienced by her characters, a conversation with the creative myth-landscape of Coyote, an effort to engage the contradictory "nature" of a specific locality.

Watson's experience is similar to that of other authors who, according to Gary Snyder, found in the Trickster an antidote to the oversimplified and placeless colonial narratives of previous Western writers: "Coyote, as I said, was interesting to me and some of my colleagues because he spoke to us of place, because he clearly belonged to the place and became almost like a guardian, a protector spirit" (The Old Ways 83-84). Consequently, the contemporary Coyote is not merely a singular disruptive element that "speaks" a particularly locality, but is instead the personified invocation of a fluid landscape that is based on transformative principles, a "Coyote universe" where such modernist givens as fixity, structure, predictability, and the controllability of nature break down in the watchful presence of the Trickster. Such a cosmology is closely aligned with the broad postmodern conception of nature which, as Max Oelschlaeger articulates in The Idea of Wilderness (1991), recognizes that "there are fixities beyond human control" (336), and that "we must not forget, even for a moment, that we are not the end or raison d'etre of evolutionary process but merely a coordinate interface" (350).

The mediating Coyote-Trickster of the extended pre-modern self can provide the conceptual vehicle for the postmodern human to move across this coordinate interface and re-establish a viable philosophical relationship with the natural world. Because the analogic "cross over" world of the Trickster-Coyote does not reduce the natural world to a status of mere dissociated and meaningless matter that is subject to human control, it instead produces a world of multiple and purposeful subjects which meet, intermingle, and eventually try to imitate rather than dominate one an- 
other. The Coyote universe therefore offers the potential for a heightened subjective awareness of ecological interrelationships, a worldview that provides a workable means to resist the monolithic and exclusionary categories of the modern imagination. As Donna Haraway suggests in Simians, Cyborgs, and Women: The Reinvention of Nature (1991), "the world resists being reduced to mere resource because it is-not mother/matter/ mutter-but coyote, a figure for the always problematic, always potent tie of meaning and bodies" (201). More than this, it is the mediative Coyote that provides the metaphysical fuel with which to navigate the intersection between physical being and conceptual meaning, and thus create a community of shared symbolism and intentionality within the natural world. Coyote is, as the actor/writer Peter Coyote reminds us in "Muddy Prints on Mohair," not merely an iconoclast, but a "community man" (Bright 102). His outrageous behavior, his indefatigable vitality, and his polyphonic laughter all serve to remind us of the broad set of relationships that exist "out there" in the forest. These relationships are not us, and are certainly something which is not controllable by us; they are something to which Coyote connects us through our shared experience of being alive.

Perhaps this is what the poet and environmental activist Lewis MacAdams had in mind in "Callin' Home Coyote" (included in his News From Nimian Farm [1976]) when his imagined Coyote reminds humans that

\section{You must got to remember, Illumination. \\ You got to give off some illumination or the rest of us be thinkin that the humans want it all for themselves. (27)}

By refusing to share "illumination," or subjecthood, with Coyote and other members of the nonhuman world, human beings refuse to participate in that world; refuse, in effect, to abandon their imperial sense of control over the universe. Coyote offers a way out of this dilemma, a symbolic landscape that is not entirely a human construct, but a set of variable patterns and boundaries that collapse toward each other in the liminal phase of heightened poetic sensitivity. Aldo Leopold's $A$ Sand County Almanac (1949) has described this experience as "thinking like a mountain" (132), but the symbol he chose was too permanent, too immovable, and too remote to convey a full range of expressive possibilities. North Americans might do better to invoke the fluid and flexible Trickster-Coyote as a "presence" to move us beyond the modern dilemma of the natural alien. We might do better, in the end, to try thinking like a coyote. 


\section{Coyote's Calling}

It is perhaps too easy to lose sight of the "real" coyote in any discussion of the animal's recent literary and philosophical manifestations. The coyote is, we must remind ourselves, a "half mental/half mammal being" (Bright 101), one whose mythic revival is continually informed by his biological capacities for survival. Indeed, the biological coyote is no less an exponent of the Trickster-universe than is his mythic cousin. As we have seen, the coyote is almost unique among large mammals for defying human control practices. Despite more than one hundred years of human manipulation, the coyote population continues to resist development by killing livestock, stealing fruit and vegetables from fields or delivery trucks, and "competing" with hunters for their trophies. Some coyotes have even taken to a kind of monkey wrenching environmental activism by digging up and chewing through the irrigation pipes of avocado producers (Wade 347-365). Like his mythical cousin, the biological animal's cross-over thievery continually reminds us, if somewhat forcefully, that the living world does not manifest itself solely for human purposes. Indeed, the coyote continues to confuse and confound the human effort to create a wholly planned, predictable, and "developed" world, a constant reminder of the spirited disorder that exists in violation of physical boundaries created by the modern human imagination.

However, as with the mythic Coyote, the biological coyote is not merely an outlaw; he also offers the possibility for extended community-based relationships with the natural world. His "interference" with the human world provides the direct carry-over capacity necessary for inter-species relationships in a variety of specific places. Indeed, just as the human species has become more urbanized and less "natured" in the late modern period, so the coyote has followed along beside us, the only large carnivore, it seems, that can survive in the fragmented natural environments of the rural and urban landscape. Coyotes have prospered in such western cities as Vancouver, Los Angeles, and Seattle, and they have more recently arrived in the eastern megalopolises of New York and Toronto. They have, in many cases, re-inhabited golf courses, protected stream banks, forest fragments, and city parks, refusing to "give ground" as suburban sprawl expands the boundaries of many city structures. Here, the animals drink from the numerous swimming pools, eat the odd pet, and have even been heard singing in response to musical concerts at the open air Hollywood Bowl in Los Angeles (Gill and Bonnett 87-108).

Thus, the urban coyote has managed to commit a subversive act by 
staking a claim to wildness in the largely human-controlled environment of the city. Moreover, despite some "bigoted" responses and control campaigns, the presence of a large animal such as the coyote has begun to capture the imaginations of many city residents, perhaps the precursor of what the geographer Jennifer Wolch has described as a "renaturalized, re-enchanted city zoöpolis" that allows for "the reintegration of people with animals and nature" and "provide[s] urban dwellers with the local, situated everyday knowledge of animal life required to grasp animal standpoints or ways of being in the world, interact with them accordingly in particular contexts, and motivate political action necessary to protect their autonomy as subjects and their life spaces" (29). Several celebratory articles about the urban coyote have recently appeared in (of all places) The Economist, as well as the two major Canadian daily newspapers. Several book chapters, and even a recent children's book, have also devoted themselves to the subject. In more direct terms, resident groups in Los Angeles have actively petitioned against control efforts and for the protection of coyote habitat because, according to the results of a study by the anthropologists Don Gill and Penelope Bonnett, "the presence of the coyote near their homes gave them a satisfying sense of intimacy with nature" (107).

Perhaps, then, the coyote's reinhabitation of the city does, in very direct terms, offer urban dwellers the mediative conceptual space to move from a less domesticated to a "wilder" state of consciousness. Wolch suggests that zoöpolis "asks for a future in which animals and their nature would no longer be incarcerated beyond the reach of our everyday lives, leaving us with only cartoons to heal the wounds of their absence" (47). In other words, the cardboard "cut out" world of the petstricken and Disneyfied human imaginings of animals might just give way to a heightened consciousness of the "others" in the (meta)physical presence of the coyote. The poet Barry Gifford describes the "common hallucination" of seeing a coyote in Brooklyn, a shared experience of "uniqueness" and "spontaneous ecstasy" that "gave birth" to his elevated awareness of the animal (Coyote Tantras, book III, no. XCVII). As Gifford's experience suggests, the presence of Coyote in the city presents an opportunity to bridge the concrete consciousness of the urban world to the organic consciousness of wild nature, a boundary crossing exercise that offers urban dwellers an accentuated experience of the natural world. This extension of the urban self to embrace the alien other may signal the beginning of a larger reparation of the pathological human relationship to the coyote. The urban presence of coyotes may teach us to point to the animal rather than at him; teach us, in the end, to learn to live with rather than without the coyote. 


\section{The Past and Future Coyote}

In May of 1974, the avant-garde artist Joseph Beuys crossed the Atlantic from Europe to America, arrived at Kennedy airport, and, wanting no part of contemporary America, covered himself in a robe before he was transported by ambulance to New York's René Block Gallery. Beuys's sole purpose was to meet a coyote, and he spent a week living behind a wire cage with one animal in the full public view of gallery patrons. He traded music with the coyote, dozed with him, and presented gift objects with which the animal could play. Caroline Tisdall, the photographer who recorded the event explains, in Joseph BeuysCoyote (1976), the artist's purpose as follows:

The crossing point of energy and trauma in Europe and Eurasia was a constant theme in Beuys' work. With "Coyote" he concentrates on an American equivalent which he feels has effected the course of history of the United States: "I believe I made contact with the psychological trauma point of the United States' energy constellation: the whole American trauma with the Indian Red Man."

This is where the figure of the coyote appears, respected and venerated by the Red Man, despised and persecuted by the White Man: a polarity and a gulf. Somehow the trauma has to be reversed and amends made: "you could say that a reckoning has to be made with the coyote, and only then can this trauma be lifted." (24)

Beuys's attempts to come face to face with the gulf between himself and the coyote was, in effect, an effort to create a sustaining mythology to move us beyond the mental categories of the modern imagination. For Beuys, the coyote is unique among animals for possessing "the attributes of spiritual transformation," a power that "is so mighty that the human being cannot understand what it is, or what it can do for humankind in the future" (quoted in Tisdall 26). Beuys's work therefore re-emphasizes the central purpose of the pre-modern Coyote myths (to carry humans over from the known to the unknown, from the world of the encapsulated self to the world of the Other), but remains unique among recent works of art because the attempt to do so takes place in the presence of a real coyote. Unlike other artists, Beuys' expression of the coyote is not a symbol or metaphor, but an actual animal who eats, sleeps, and urinates on the floor of an art gallery in New York City. The result is not simply a re-enchantment of the world using the mythic presence of the coyote, but also the re-enchantment of the biological or "real" coyote. In the most compelling sense, Beuys's work takes a garbage animal and offers it the possibility of godhood once again. 
Beuys's re-sacrilization of the biological coyote also offers a larger staging ground for an existential leap in human relationships with the nonhuman world. His redemptive meeting with the coyote offers a way of re-defining the liminal space between the real and the mythic; between the sacred and profane; and between the modern and pre-modern conceptions of animals. In Giving Birth To Thunder, Sleeping With His Daughter (1977), Barry Lopez speaks of this process as "a renegotiation of the contracts" between humans and nonhumans, a conversation in which Coyote's metaphoric carry-over potential may allow for a "cultivation of mystery and awe that has kept our capacity for metaphor intact," allowing us "to perceive animals not only as complex physiological organisms but as elements of a coherent and shared landscape" (18).

Ursula LeGuin expands on this possibility in "Buffalo Gals, Won't You Come Out Tonight," her story of a small girl who lives in the "other" world of animals following her near-death in a plane crash. It is, of course, Coyote who rescues and cares for the girl, an expression of "craziness" that distinguishes the Trickster from all other animals. Coyote becomes a guide for the girl, and enables her to negotiate a place within a world of absolute others because "she [Coyote] wasn't afraid. She went between the two kinds of people. She crossed over" (39). LeGuin's story reiterates the failure of all humans but her child protagonist to adopt this "coyote consciousness" as the animal's mythic status is reduced to mere dead matter when she eats poison bait near the end of the story. Without her transitional guide, the little girl must then return to the fixed boundary world of humans, and thus experience the coyote merely as an animal who "gets killed all the time" (59).

Perhaps this is the true crossroads at which we human beings stand in our relationship to the coyote, a choice between the dubious certainty of the humanized world and a newly mythologized Coyote universe that promises to sustain us in our own hopeful transition through the stifling failure of our self-imposed natural alienation. The works of Beuys, LeGuin, and many of the other artists discussed in this chapter are pointing us in the latter direction. So, too, is the biological coyote, an animal of "resolute paradox" that is the embodiment of an antidomestic consciousness; the embodiment, indeed, of wildness itself.

However, there are still many who would prefer that this quality of wildness be actively removed from the realm of human experience. The survival of the coyote in spite of humanity's stifled imagination and biocidic tendencies remains an evocative challenge to the "ordered" and developed world imagined by advocates of human-centered progress, offering an alternative conceptual space to live in association with, rather than against, a spontaneous and ecstatic vision of wild nature. Still, despite such possibilities, the critic Paul Shepard has suggested, despair- 
ingly, that the only animal of any significance in the post-apocalyptic world of ecological collapse will be the ever-adaptable domestic goat. I am, I suppose, more hopeful. I think it will be the coyote.

\section{NOTE S}

1. I must apologize at this point for my use of the masculine pronoun to describe Coyote throughout the essay. I follow this convention out of respect for the traditional depiction of Coyote as male in Native mythology.

2. Thomas Say was the first biologist to see a coyote, and remarked that the animal was "probably the original of the domestic dog so common in the villages of the Indians, some varieties of which still retain the habit and manner of the species." Paul Wilhelm, who lived with the Plains Indians from 1822 to 1823 noted that "their dogs have pointed ears and a drooping tail. They constitute a species as unique as the dingo. They seem to have been bred up originally from the coyote. They howl, but they do not bark; they growl and bristle up their hair; they approach one quietly and bite without warning." The naturalist J.K. Lord suggested that the dog of the Spokane Indians was "beyond all question nothing more than a tamed coyote" The above quotations are from Frank J. Dobie's The Voice of Coyote (177-78).

3. The coyote still hunts with the badger by "guarding" the exit holes in prairie dog towns to trap the prey species and increase both of the predators' chances for success. While the coyote and badger do form a most remarkable and mutually beneficial interspecies relationship, the relationship is not facile (i.e., the two species are not "friends" as in the Disneyfied imagination), but they remain tolerant of each other. The Coyote and Badger of myth have much the same relationship, hunting together, but forever stealing from, and wary of, the other party. See "Coyote and Badger" in William Bright's A Coyote Reader (124-130). For a biological account, see Kathryn A. Minta and Steven C. Minta's "Partners in Carnivory: North America's Coyotes and Badgers Have an Ancient Bond" in the June 1996 issue of Natural History (60-62).

4. My main sources for Coyote stories were the cited volumes by Mourning Dove, William Bright, and Jarold Ramsey. Other useful sources are the volumes by Berard Haile, and Barry Lopez (though the author has taken great license with the stories); and William Bright's collection of "straight" translations found in Coyote Tales (Native American Texts Series, Monograph No. 1). Wherever possible when I am quoting material, I will favour Bright's Coyote Reader because of the "ethnopoetic" translations whereby the stories are arranged true to their original form as oral verse.

5. See Andrew Wiget's Recovering the World: Essays on Native American Literature (255-296). See, also, any broad collection of Coyote tales.

R E F E R E N C E S

Bennett, Bruce. "Coyote in Love." A Coyote Reader. Ed. William Bright. Berkeley: California UP, 1993. 72.

Bright, William, trans. "Coyote and Badger." A Coyote Reader. Ed. William 
Bright. Berkeley: U of California P, 1993. 124-30.

, ed. Coyote Tales (Native American Texts Series, Monograph No. 1). Chicago: U of Chicago P, 1978.

Canadian Wildlife Service. Coyote. Ottawa: Dept. of Supply and Services, 1977.

Coyote, Peter. "Muddy Prints on Mohair." A Coyote Reader. Ed. William Bright. Berkeley: U of California P, 1993. 100-04.

De Angulo, Jaime. Indian Tales. New York: Hill and Wang, 1953.

Dobie, Frank J. The Voice of Coyote. Lincoln: U of Nebraska P, 1949.

Gifford, Barry. Coyote Tantras. Santa Barbara: Christopher's Books, 1978.

Gill, Don, and Penelope Bonnett. Nature in the Urban Landscape. Baltimore:

York P, 1973.

Grady, Wayne. Toronto the Wild. Toronto: McFarlane, Walter and Ross, 1995.

Haile, Berard. Navajo Coyote Tales. Lincoln: U of Nebraska P, 1984.

Haraway, Donna. Simians, Cyborgs, and Women: The Reinvention of Nature. London: Free Association Books, 1991.

Howard, Victoria, and Melville Jacobs, trans. "Coyote Sucks Himself." A Coyote Reader. Ed. William Bright. Berkeley: U of California P, 1993. 70-72.

Hymes, Dell. "Fivefold Fanfare for Coyote." A Coyote Reader. Ed. William Bright. Berkeley: U of California P, 1993. 50-54.

Jung, Carl. "The Psychology of the Trickster Figure." The Trickster. Ed. Paul Radin. New York: Greenwood, 1953. 195-211.

Kane, Sean. The Wisdom of the Mythtellers. Peterborough: Broadview P, 1994.

King, Thomas. "A Coyote Columbus Story." One Good Story, That One. Toronto: HarperCollins, 1993. 119-127.

- Green Grass, Running Water. Toronto: HarperCollins, 1993.

Leahy, Stephen. "Wile E. Coyote Comes to Town." Toronto Star. March 1, 1997: B6.

Mason Lee, Robert. "Wile E. Coyote Moves to the Big Smoke." The Globe and Mail. February 3, 1996: D8.

LeGuin, Ursula K. "Buffalo Gals, Won't You Come Out Tonight." Buffalo Gals and Other Animal Presences. New York: Penguin, 1987.

Leopold, Aldo. A Sand County Almanac and Sketches Here and There. 1949. New York: Oxford UP, 1987. 129-133.

Lévi-Strauss, Claude. Myth and Meaning. London: Routledge, 1978.

Lopez, Barry. Giving Birth To Thunder, Sleeping With His Daughter. Kansas City, MO: Andrews \& McMeel, 1977.

_ . "Renegotiating the Contracts." Parabola 8 (Spring 1993): 14-19.

MacAdams, Lewis. "Callin' Home Coyote." News From Nimian Farm. Bolinas: Tomboctou, 1976. 26-29.

Minta, Kathryn A. and Steven C. Minta. "Partners in Carnivory: North America's Coyotes and Badgers Have an Ancient Bond." Natural History (June 1996): 60-62.

Mourning Dove. Coyote Tales (1933). Lincoln: U of Nebraska P, 1990.

Murillo, Alejandrina, trans. "Coyote Baptizes the Chickens." A Coyote Reader.

Ed. William Bright. Berkeley: U of California P, 1993. 89-91.

Oelschlaeger, Max. The Idea of Wilderness. New Haven: Yale UP, 1991.

Ortiz, Simon J. Woven Stone. Tucson: U of Arizona P, 1992.

Phelan, Shane. "Coyote Politics: Trickster Tales and Feminist Futures." Hypatia 11.3 (Summer 1996): 130-50.

Ramsey, Jarold, trans. "Coyote Establishes the Fishing Taboos." A Coyote 
Reader. Ed. William Bright. Berkeley: U of California P, 1993. 38-42.

. Coyote Was Going There: Indian Literature of the Oregon Country. Seattle:

U of Washington P, 1977.

. Reading the Fire: Essays in the Traditional Indian Literature of the Far West.

Lincoln: U of Nebraska P, 1983.

. "Res in urbe (Coyotes moving into New York and Other Cities)," The

Economist 335.7918 (1995): 75.

Seton, Ernest Thompson. Lives of the Hunted. Toronto: Morang and Co., 1901.

Scott, Tacheeni, and Barre Toelken. "Poetic Retranslation and the 'Pretty

Languages' of Yellowman." Traditional Literatures of the American Indian. Ed.

Karl Kroeber. Lincoln: U of Nebraska P, 1981. 65-116.

Shepard, Paul. The Others. Washington, DC: Island P, 1996.

Snyder, Gary. "The Berry Feast." The Back Country. New York: New Directions, 1957. 1-4.

The Old Ways. San Francisco: City Lights, 1977.

Swanson, Diane. Coyotes in the Crosswalk. Toronto: Whitecap, 1994.

Tisdall, Caroline. Joseph Beuys—Coyote. München: Grimm and Bleicher, 1976.

Wade, Dale A. "Coyote Damage: A Survey of its Nature and Scope, Control Measures and Their Application." Coyotes: Biology, Behavior, Management. Ed. Mark Bekoff. Boulder: U of Colorado P, 1978. 347-365.

Watson, Sheila, The Double Hook. Toronto: McClelland and Stewart, 1959.

Wiget, Andrew. "Telling the Tale: A Performance Analysis of a Hopi Coyote

Story" Recovering the World: Essays on Native American Literature. Ed. Brian

Swann and Arnold Krupat. Berkeley: U of California P, 1987. 255-296.

Wolch, Jennifer. "Zoöpolis." Capitalism, Nature, Socialism. 7.2 (June 1996): 29-47. 